Communication

\title{
$\beta$-Caryophyllene: A Single Volatile Component of n-Hexane Extract of Dracaena cinnabari Resin
}

\author{
Mohamed Al-Fatimi \\ Department of Pharmacognosy, Faculty of Pharmacy, Aden University, P.O. Box 5411 (Maalla), Aden 00967-2, \\ Yemen; alfatimi@web.de \\ Academic Editor: William Setzer \\ Received: 3 September 2020; Accepted: 22 October 2020; Published: 26 October 2020

\begin{abstract}
The pure Soqotri resin of Dracaena cinnabari Balf.f. (Dracaenaceae) has no volatile smell due to its low content of volatile constituents. Although it is insoluble in $n$-hexane, we found that the resin, when suspended in $n$-hexane within five days at $5{ }^{\circ} \mathrm{C}$, led to the extraction of a small portion of a single volatile liquid constituent, which was identified by GC-MS as sesquiterpene $\beta$-caryophyllene. This method of extracting the volatile constituents using hexane under cooling is very suitable for resins of the Dracaena species because these resins usually contain very few volatile terpenes and/or non-terpenes, and they may contain only one volatile terpene per resin as this study result. $\beta$-Caryophyllene was identified and separated for the first time from the Soqotri standard resin of Dracaena cinnabari. Therefore, $\beta$-caryophyllene, as a new chemical property, can support to evaluate the purity of the Soqotri resin. Moreover, a big mass of $D$. cinnabari resin can yield concentrated $\beta$-caryophyllene as a liquid extract for further pharmaceutical and nutraceutical applications.
\end{abstract}

Keywords: Dracaena cinnabari; resin; $\beta$-caryophyllene; GC-MS; Soqotra

\section{Introduction}

Several phenolic derivatives have been isolated and identified in the resins of different species of Dracaena; for example, $D$. cinnabari resin, which mostly contains flavonoids [1]. The volatile content of the resin has been rarely studied due to the difficulty of the solubility of the resin in nonpolar solvents such $n$-hexane and due to the very low content of the volatile oil in the resin that cannot be obtained by the method of water distillation. However, the headspace method has been previously used to identify some volatile terpenes in the resin [2]. In this study, we studied a method to obtain the volatile content of the $D$. cinnabari resin by $n$-hexane extraction for five days under low temperature.

$\beta$-Caryophyllene has been reported as an antimicrobial, antioxidant, and cytotoxic agent [3-5]. These results explain that the combination of $\beta$-caryophyllene and polyphenols can insert a strong synergist effect on the biological and pharmacological activities of the Soqotri resin including its activities against cancer cell lines [6].

\section{Results and Discussion}

The Soqotri standard resin of Dracaena cinnabari is insoluble in $n$-hexane [1] due to its rare content of volatiles. This was identified by the non-volatile odor of the pure resin [1]. However, in the present study, we found that by suspending the powdered resin in the $n$-hexane at a low temperature of $5{ }^{\circ} \mathrm{C}$ for five days, it could release a pure compound that dissolved in a small portion in the $n$-hexane. This $n$-hexane filtrate of the resin was investigated by GC-MS. The result identified $\beta$-caryophyllene as a single volatile hydrocarbon component that formed the liquid part (100\% volume) of the volatile content. The calculated kovats retention index (RI) was 1416 compared to the (RI) reference of 1417, according to Adam, 2007 [7]. $\beta$-Caryophyllene (trans-(1R,9S)-8-methylene-4,11,11-trimethylbicyclo 
[7.2.0] undec-4-ene) was identified as a yellowish volatile liquid hydrocarbon bicyclic sesquiterpene (Figure 1, Table 1). The mass spectrum of the identified $\beta$-caryophyllene peak was compared to the reference mass spectrum of $\beta$-caryophyllene found in the NIST (National Institute of Standards and Technology) Mass Spectral Library (Figure 2).<smiles>C=C1CC/C=C(/C)CC[C@H]2[C@@H]1CC2(C)C</smiles>

Figure 1. $\beta$-Caryophyllene structure.

Table 1. Chemical composition of the $n$-hexane extract of the resin of Dracaena cinnabari.

\begin{tabular}{ccccc}
\hline Retention Time (min) & Compound & Content $\%$ & $\begin{array}{c}\text { Retention } \\
\text { Index } \\
\text { RI }\end{array}$ & $\begin{array}{c}\text { Retention } \\
\text { Index } \\
\text { Reference } \\
\text { RI-ref }\end{array}$ \\
\hline 20.403 & $\beta$-Caryophyllene & 100 & 1416 & 1417 \\
\hline
\end{tabular}

RI: Retention index experimentally determined on the DB-5 column relative to C10-C20 n-alkanes, the compound listed in order of its elution on the DB-5 column. RI-ref: Retention index reference according to Adam, 2007 [7].

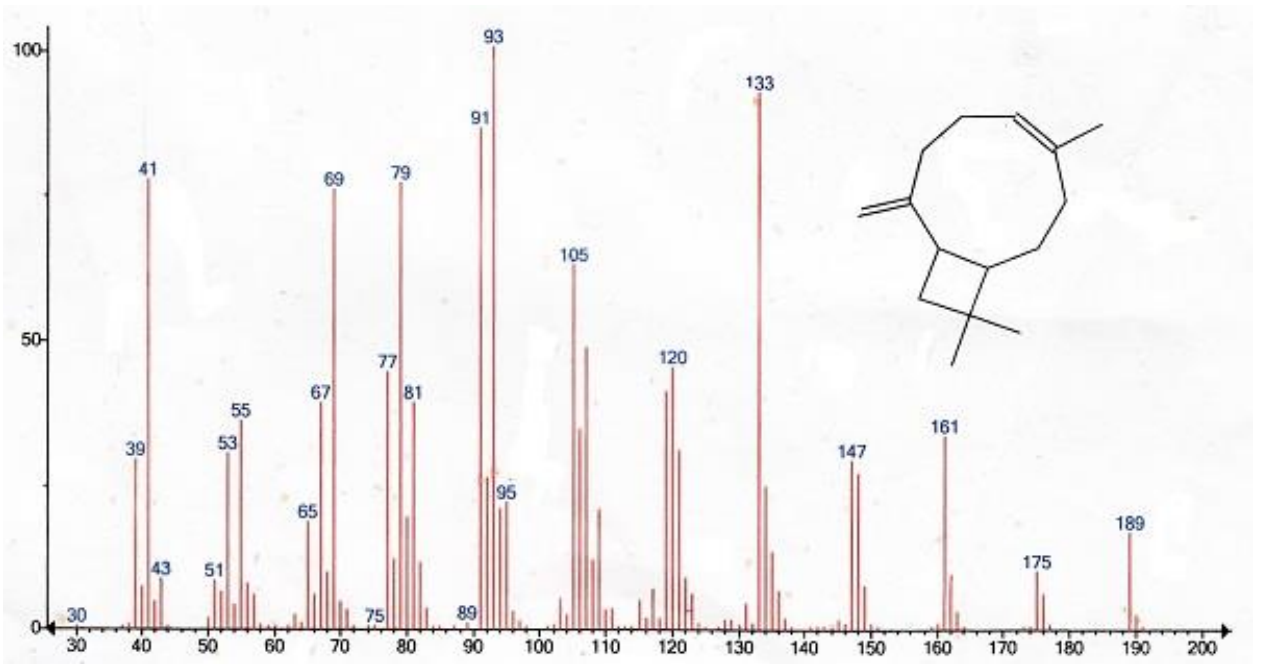

Figure 2. Mass spectrum of the identified $\beta$-caryophyllene peak compared to the reference mass spectrum of $\beta$-caryophyllene found in the NIST Mass Spectral Library.

The investigation of a resin filtrate of a non-polar solvent such as $n$-hexane under cooling might contain liquid volatile constituents, even if the resin is insoluble in this solvent. It can separate a volatile pure compound or mixture of volatile constituents. These volatile constituents can be identified in the solvent filtrate by GC-MS.

By the resin suspension in $n$-hexane for five days at $5{ }^{\circ} \mathrm{C}$, it reduced the volatile oxygenated terpenes that are still solid by cooling. In contrast to the volatile oxygenated terpenes, the hydrocarbon terpenes remained in liquid state even with cooling. Therefore, the liquid hydrocarbon terpenes can be dissolved in the $n$-hexane, and separated from the resin corpus.

In this study, $\beta$-caryophyllene is reported for the first time in the resin of $D$. cinnabari. On the other hand, this volatile sesquiterpene could not be identified in the resin of the D. cinnabari using 
the method of headspaces HS-SPME/GC, but other volatile monoterpenes have been identified [2]. This difference may be attributed to the use of different types of resins and different extraction methods. According to our previous study, there are many types of Soqotri resin obtained from D. cinnabari where the pure resin has no characteristic odor or only very weak volatile odor [1]. This explains the identification of only a single hydrocarbon sesquiterpene in the Soqotri pure resin, which we used in this study.

On the other hand, caryophyllene oxide, as a derivative of $\beta$-caryophyllene, was identified in the resin of other Dracaena species: D. draco subsp. ajgal from Morocco using headspaces HS-SPME/GC [2]. Nevertheless, the use of $n$-hexane in the resin of $D$. cochinchinensis from China led to the identification of the existence of only three different volatile sesquitepenes: $\tau$-cadinol, $\tau$-muurolon, and $\alpha$-cadinol [8]. This confirmed the results that the pure resins of different Dracaena species often contain volatile sesquiterpenes. This result can be used as analytical evaluation for the resin of $D$. cinnabari. Moreover, $\beta$-caryophyllene was previously identified in the fruit and leaf of Dracaena draco using the HS-SPME/GC method $[9,10]$ and in the leaf of Dracaena reflexa using the distillation method [11] (Table 2).

Table 2. Identification of $\beta$-caryophyllene in Dracaena species using different methods.

\begin{tabular}{|c|c|c|c|c|}
\hline Dracaena Species & Plant Part/Exudates & Method & $\begin{array}{l}\text { Identification of } \\
\beta \text {-Caryophyllene }\end{array}$ & Reference \\
\hline \multicolumn{5}{|l|}{ Dracaena cinnabari } \\
\hline \multicolumn{5}{|l|}{ D. serrulata } \\
\hline D. ombet & resin & HS-SPME/GC & none & [2] \\
\hline \multicolumn{5}{|l|}{$\begin{array}{l}\text { D. draco subsp. } \\
\text { draco }\end{array}$} \\
\hline \multicolumn{5}{|l|}{$\begin{array}{c}\text { D. draco subsp. } \\
\text { ajgal }\end{array}$} \\
\hline D. cochinchinensis & resin & $n$-hexane extraction & none & [8] \\
\hline D. draco & fruit & HS-SPME/GC & $\beta$-caryophyllene & [9] \\
\hline D. draco & leaf & HS-SPME/GC & $\beta$-caryophyllene & [10] \\
\hline $\begin{array}{l}\text { D. reflexa var. } \\
\text { angustqo }\end{array}$ & leaf & $\begin{array}{l}\text { steam distillate was } \\
\text { extracted into } \\
\text { hexane }\end{array}$ & $\beta$-caryophyllene & [11] \\
\hline
\end{tabular}

HS-SPME/GC: head space, solid phase microextraction with gas chromatography.

\section{Conclusions}

In general, resins of Dracaena species contain very few volatile terpenes with little content. Therefore, these resins are either slightly soluble or insoluble in some lipophilic solvents such as Dracaena cinnabari resin in $n$-hexane (1). The suspension of powdered resin in $n$-hexane for some days under cooling led to the extraction of the liquid hydrocarbon sisquiterpenes from the resin. In our study, we identified $\beta$-caryophyllene by GC-MS as a single sesquiterpene in the resin of $D$. cinnabari.

$\beta$-Caryophyllene, as a new chemical constituent, can assist in evaluating the purity of the Soqotri resin of $D$. cinnabari. $\beta$-Caryophyllene can be separated from the resin of $D$. cinnabari by $n$-hexane and concentrated for further pharmaceutical applications.

\section{Materials and Methods}

\subsection{Plant Material}

D. cinnabari resin was collected from Soqotra Island, southern Yemen. The plant was identified by the Pharmacognosy Department, Aden University, Yemen. A voucher specimen (No. MF-SOC 001) has been deposited at the personal herbarium of the author. 


\subsection{Extraction}

Ten grams of the dried and powdered resin was suspended in the $50 \mathrm{~mL} n$-hexane for five days at $5{ }^{\circ} \mathrm{C}$ and filtrated. The filtrate without reducing was kept at $4{ }^{\circ} \mathrm{C}$ until analysis by GC-MS.

\subsection{GC-MS Analysis}

The $n$-hexane filtrate of $D$. cinnabari was analyzed by an analytical GC-MS system consisting of an Agilent 6890N gas chromatograph and a mass selective detector (Agilent ${ }^{\circledR} 5973$ Network MSD, Agilent Technologies, Santa Clara, CA, USA). Injection was done with an Agilent ${ }^{\circledR} 7683$ Series Injector (Split 1:40 at $250{ }^{\circ} \mathrm{C}, 2.0 \mu \mathrm{L}$; carrier gas: helium $1.1 \mathrm{~mL} / \mathrm{min}(60 \mathrm{kPa})$ at $110{ }^{\circ} \mathrm{C}$; pressure rise: $\left.6 \mathrm{kPa} / \mathrm{min}\right)$. The MS was operated in the electron impact mode with an ionization energy of $70 \mathrm{eV}$. The oven program started with $1 \mathrm{~min}$ at $70{ }^{\circ} \mathrm{C}$, then the oven temperature was increased at $3{ }^{\circ} \mathrm{C} / \mathrm{min}$ to $220^{\circ} \mathrm{C}$. Full scan mass spectra were acquired from $35-350 \mathrm{~m} / \mathrm{z}$ at a rate of $4.5 \mathrm{scans} / \mathrm{s}$ and with a $5.00 \mathrm{~min}$ solvent delay. Chromatography was performed using a $30 \mathrm{~m}$ DB-5 column (J\&W Scientific, Folsom, CA, USA) with $0.25 \mathrm{~mm}$ i.d. and $0.25 \mu \mathrm{m}$ film thickness. The detected compounds were identified by processing the raw GC-MS data with ChemStation G1701CA software and comparing them with the NIST mass spectral database $2.0 \mathrm{~d}$ (National Institute of Standards and Technology, Gaithersburg, MD, USA) and from the retention indices and mass spectra of standard compounds. Relative amounts of detected compounds were calculated based on the peak areas of the total ion chromatograms (TIC).

Funding: This research received no funding.

Acknowledgments: I thank Ulrike Lindequist, Institute for Pharmacy, University Greifswald, Germany, for giving me the opportunity to work in her laboratory.

Conflicts of Interest: The author declares no conflict of interest.

\section{References}

1. Al-Fatimi, M. Ethnobotanical Survey of Dracaena cinnabari and investigation of the pharmacognostical properties, antifungal and antioxidant activity of its resin. Plants (Basel) 2018, 7, 91. [CrossRef] [PubMed]

2. Vaníčková, L.; Pompeiano, A.; Maděra, P.; Massad, T.J.; Vahalík, P. Terpenoid profiles of resin in the genus Dracaena are species specific. Phytochemistry 2020, 170, 112197. [CrossRef]

3. Sabulal, B.; Dan, M.; Kurup, A.J.J.R.; Pradeep, N.S.; Valsamma, R.K.; George, V. Caryophyllene-rich rhizome oil of Zingiber nimmonii from South India: Chemical characterization and antimicrobial activity. Phytochemistry 2006, 67, 2469-2473. [CrossRef] [PubMed]

4. Sain, S.; Naoghare, P.K.; Devi, S.S.; Daiwile, A.; Krishnamurthi, K.; Arrigo, P.; Chakrabarti, T. Beta caryophyllene and caryophyllene oxide, isolated from Aegle marmelos, as the potent anti-inflammatory agents against lymphoma and neuroblastoma cells. Antiinflamm Antiallergy Agents Med. Chem. 2014, 13, 45-55. [CrossRef]

5. Kubo, I.; Chaudhuri, S.K.; Kubo, Y.; Sanchez, Y.; Ogura, T.; Saito, T.; Ishikawa, H.; Haraguchi, H. Cytotoxic and antioxidative sesquiterpenoids from Heterotheca inuloides. Planta Med. 1996, 62, 427-430. [CrossRef] [PubMed]

6. Al-Fatimi, M.; Friedrich, U.; Jenett-Siems, K. Cytotoxicity of plants used for traditional medicine in Yemen. Fitoterapia 2005, 76, 355-358. [CrossRef] [PubMed]

7. Adams, R.P. Identification of Essential Oil Components by Gas. Chromatography/mass Spectrometry, 4th ed.; Allured Publishing Co.: Carol Stream, IL, USA, 2007.

8. Teng, Z.; Zhang, M.; Meng, S.; Dai, R.; Meng, W.; Deng, Y.; Huang, L. A comparative study on volatile metabolites profile of Dracaena cochinchinensis (Lour.) SC Chen xylem with and without resin using GC-MS. Biomed. Chromatogr. 2015, 29, 1744-1749. [CrossRef] [PubMed]

9. Santos, R.P.; Mendes, L.S.; Silva, B.M.; de Pinho, P.G.; Valentao, P.; Andrade, P.B.; Pereira, J.A.; Carvalho, M. Phytochemical profiles and inhibitory effect on free radical-induced human erythrocyte damage of Dracaena draco leaf: A potential novel antioxidant agent. Food Chem. 2011, 124, 927-934. [CrossRef] 
10. Silva, B.M.; Santos, R.P.; Mendes, L.S.; de Pinho, P.G.; Valentão, P.; Andrade, P.B.; Pereira, J.A.; Carvalho, M. Dracaena draco L. fruit: Phytochemical and antioxidant activity assessment. Food Res. Int. 2011, 44, 2182-2189. [CrossRef]

11. Gurib-Fakim, A.; Demarne, F. Volatile constituents of Dracaena reflexa Lam. var. angustifolia Baker. J. Essent. Oil Res. 1994, 6, 651-652. [CrossRef]

Sample Availability: Samples of the compound are not available.

Publisher's Note: MDPI stays neutral with regard to jurisdictional claims in published maps and institutional affiliations.

(C) 2020 by the author. Licensee MDPI, Basel, Switzerland. This article is an open access article distributed under the terms and conditions of the Creative Commons Attribution (CC BY) license (http://creativecommons.org/licenses/by/4.0/). 